Давидова Жанна Вадимівна кандидат педагогічних наук, доцент, доцент кафедри гуманітарних та соціально-економічних дисциплін, ПВНЗ “Харківський міжнародний медичний університет”, вул. Героїв праці, 19, кв.144, м. Харків, 61144, тел.: (050) 597-99-34, https://orcid.org/0000-0002-7514-8910

\title{
АНАЛІЗ ОСОБЛИВОСТЕЙ НАВЧАННЯ СТУДЕНТІВ-ІНОЗЕМЦІВ У ВІТЧИЗНЯНІЙ ВИЩІЙ ШКОЛІ
}

Анотація. У статті проаналізовано особливості навчання студентівіноземців у вітчизняній вищій школі. Відзначено, що в Україні за період останнього десятиріччя вітчизняні заклади вищої освіти зайняли належне місце за кількістю іноземних здобувачів у світовому освітньому просторі. Це сприяє, насамперед, підвищенню конкурентоспроможності вітчизняної вищої освіти на світовому ринку освітніх послуг. Здобуття вищої освіти в Україні визначається престижністю та затребуваністю серед іноземних студентів, оскільки вони отримують фундаментальну освіту за престижними спеціальностями у вишах, що забезпечує високий рівень конкурентоспроможності на світовому ринку праці. Визначено фактори, які враховуються іноземними абітурієнтами при здійсненні вибору закладу вищої освіти України, серед яких міжнародне визнання наукових досягнень вітчизняних закладів вищої освіти; використання ефективних методів навчання; якість освіти; престижність та фінансова вигідність; наявність рівних прав, свободи, обов'язків під час проживання в Україні. Проаналізовано зміст поняття «експорт освітніх послуг» у контексті сучасних тенденцій розвитку вищої освіти. Розглянуто етапи та суб'єкти здійснення експорту освітніх послуг іноземним студентам. Відзначено, що іноземні студенти зазвичай мають певні труднощі, проблеми, бар'єри, ризики тощо, оскільки вони попадають у нове мовне та соціокультурне середовище. Окреслено роль навчання іноземних студентів на факультеті 3 підготовки іноземних громадян вітчизняних університетів. Зазначено, що протягом періоду навчання на підготовчому відділенні вони мають можливість, завдяки планомірній організації навчання, соціокультурно адаптуватися до життя та навчання у новому середовищі.

Ключові слова: навчання, студенти-іноземці, заклади вищої освіти, експорт освітніх послуг, соціокультурна адаптація, факультет 3 підготовки іноземних громадян. 
Журнал«Герстективита інновації наукиљ

(Серія«Гедагогіка», Серія «Геихологія», Серія «Медицина»

№(6) 2022

Davydova Zhanna Vadymivna Candidate of Pedagogical Science, associate professor, associate professor of the department of humanitarian and socialeconomic disciplines, PIHE "Kharkiv International Medical University", Heroiv Pratsi St., 19, app.144, Kharkiv, 61144, tel.: (050) 597-99-34, https://orcid.org/00000002-7514-8910

\title{
ANALYSIS OF PECULIARITIES OF INTERNATIONAL STUDENTS TRAINING IN THE SYSTEM OF HIGHER EDUCATION OF UKRAINE
}

\begin{abstract}
The article analyzes the peculiarities of training foreign students in domestic higher education. It is noted that in Ukraine over the past decade, domestic higher education institutions have taken their rightful place in the number of foreign applicants in the global educational space. This contributes, first of all, to increasing the competitiveness of domestic higher education in the global market of educational services. Higher education in Ukraine is determined by the prestige and demand among foreign students, as they receive a basic education in prestigious specialties in higher education, which ensures a high level of competitiveness in the global labor market. Factors that are taken into account by foreign entrants when choosing a higher education institution of Ukraine are identified, including international recognition of scientific achievements of domestic higher education institutions; use of effective teaching methods; quality of education; prestige and financial profitability; availability of equal rights, freedoms and responsibilities while living in Ukraine. The content of the concept of "export of educational services" in the context of current trends in higher education is analyzed. The stages and subjects of export of educational services to foreign students are considered. It is noted that international students usually have certain difficulties, problems, barriers, risks, etc., as they find themselves in a new language and socio-cultural environment. The role of education of foreign students at the faculty of training foreign citizens of domestic universities is outlined. It is noted that during the period of study at the preparatory department, they have the opportunity, thanks to the planned organization of training, to adapt socio-culturally to life and study in a new environment.
\end{abstract}

Keywords: education, foreign students, institutions of higher education, export of educational services, socio-cultural adaptation, faculty of training foreign citizens.

Постановка проблеми. Сучасні тенденції розвитку вищої освіти спрямовані на забезпечення інтенсивної взаємодії та встановлення контактів між закладами вищої освіти різних країн світу. Експорт освітніх послуг та інтеграція у світовий освітній простір $є$ найактуальнішими. Для вищої освіти в Україні розширення та популяризація надання освітніх послуг насамперед позитивно впливає на економічний розвиток, оскільки підготовка майбутніх фахівців 3 інших країн $\epsilon$ окремою статтею національного доходу. Також прагнення залучити студентів-іноземців спонукає заклади вищої освіти 
формувати систему підготовки фахівців відповідно вимог світового ринку праці до якості освіти та напрямів підготовки фахівців [1;2].

Статистика свідчить про те, що в Україні за період останнього десятиріччя вітчизняні заклади вищої освіти зайняли належне місце за кількістю іноземних здобувачів у світовому освітньому просторі, що сприяє, насамперед, підвищенню конкурентоспроможності вітчизняної вищої освіти на світовому ринку освітніх послуг. У контексті цього Кабінетом Міністрів України 21 квітня 2021 року №350-р було видано розпорядження «Про затвердження плану заходів щодо популяризації можливостей здобуття вищої освіти в Україні для іноземних студентів до 2025 року» [3] відповідно до Указу Президента України «Про вдосконалення вищої освіти в Україні» (2 червня 2020 року №210/2020) [4].

Аналіз останніх досліджень і публікацій. Проблемі підготовки іноземних студентів в системі вищої освіти України присвячено дослідження О.Білоус, В.Головко, Т.Кононової, А.Осипенко, О. Сегеда, В.Стрельцової, І.Штеймілер та інших науковців.

Мета статті. Проаналізувати сучасний стан 3 підготовки іноземних студентів у системі вищої освіти України та визначити особливості.

Виклад основного матеріалу. Україна посідає перше місце у світі серед інших країн за кількістю іноземних студентів, які навчаються у закладах вищої освіти. Здобуття вищої освіти в Україні визначається престижністю та затребуваністю серед іноземних студентів, оскільки вони отримують фундаментальну освіту за престижними спеціальностями у вишах, що забезпечує високий рівень конкурентоспроможності на світовому ринку праці. Завданням закладів вищої освіти є підготовка компетентного фахівця високого рівня та надання якісного рівня освіти усім здобувачам незалежно від їхньої національної приналежності.

Студенти, які свідомо та добровільно обирають заклад вищої освіти, чітко розуміють свою мету перебування в Україні, а це, в свою чергу, суттєво відрізняє їх від мігрантів, біженців тощо. Усвідомлене тимчасове перебування в іншій країні на період навчання пов'язане зі здобуттям вищої освіти та оволодінням обраною професією.

Л.Мазітова визначає низку факторів, які мають особливе значення для іноземних абітурієнтів при здійсненні вибору закладу вищої освіти, зокрема:

- вартість освіти;

- $\quad$ мова навчання;

- комфортність лінгвосоціокультурного середовища навчання;

- вивчення іноземних мов;

- можливість знайти після закінчення вишу й повернення на

батьківщину роботу за отриманою в ньому спеціальністю [5, с. 318].

Слід зазначити, що іноземні абітурієнти, обираючи українські 3ВО, беруть до уваги той факт, що порівняно із західноєвропейськими закладами вищої освіти в Україні значно нижча плата за навчання та відносна лояльність 
щодо вимог до рівня володіння мовою навчання при вступі. Проте, якість професійної підготовки є досить високою.

А.Корощенко та А.Джошуа, висвітлюючи досвід навчання студентівіноземців, виокремили, проаналізували та узагальнили низку переваг i недоліків через проведення опитування серед іноземних студентів. Серед переваг, було відзначено такі:

- $\quad$ найнижча плата за навчання в Свропі;

- $\quad$ після успішного закінчення бакалаврату (другий рівень вищої освіти) $\epsilon$ можливість завершити навчання в магістратурі (третій рівень вищої освіти) європейських університетів;

- висока кваліфікація та професійна компетентність професорськовикладацького складу;

- $\quad$ поважливе та толерантне ставлення усіх учасників освітнього процесу та відсутність дискримінації по відношенню до іноземних студентів тощо [6].

Серед недоліків студенти відзначають такі, як от:

- застаріла матеріально-технічна база;

- недостатня кількість англомовної навчальної літератури;

- недостатній рівень володіння іноземними мовами викладачів;

- проблеми організації побуту та дозвілля;

- відсутність інтернаціональних клубів в Україні;

- прогалина щодо залучення іноземних студентів до наукових досліджень через розрив між освітніми структурами та промисловістю різних країн тощо [6].

Тобто вибір щодо отримання вищої освіти саме в Україні для іноземних студентів зумовлений такими факторами:

- міжнародне визнання наукових досягнень вітчизняних закладів вищої освіти;

- $\quad$ використання ефективних методів навчання;

- якість освіти;

- престижність та фінансова вигідність;

- наявність рівних прав, свободи, обов'язків під час проживання в Україні [7].

Останнім часом замість словосполучення «надання освітніх послуг іноземним студентам» часто використовують альтернативне, а саме «експорт освітніх послуг», що визначається як нова економічна категорія 3 особливим змістом. Особливий зміст пояснюється тим, що надання освітніх послуг іноземним студентам є набагато складнішим та важчим процесом у порівнянні 3 наданням освітніх послуг вітчизняним студентам. Слід зазначити, що вживання дефініції «експорт освітніх послуг» у науковому просторі зовсім не суперечить світовій практиці, а навпаки наслідує їі [8, с.15].

Так, Д.Плинокос пропонує виокремити такі етапи здійснення експорту освітніх послуг іноземним студентам: 


\section{1. Інічіюючий (проведення рекламно-інформаційних кампаній, співбесід).}

2. Початковий (отримання візи, зустріч студента, реєстрація за місцем навчання).

3. Основний (безпосереднє навчання студента у закладі вищої освіти, тобто здійснення експорту освітніх послуг).

4. Завершальний (завершення експорту освітніх послуг, виїзд 3 країни) [9, с.15].

Аналізуючи вище представлені етапи, слід зазначити, що фактично саме на основному етапі здійснюється експорт освітніх послуг іноземним студентам. Цей етап найтриваліший та найважливіший, але тісно пов'язаний 3 попередніми та наступними етапами. Чим складніша структура здійснення експорту освітніх послуг, тим більше різних суб'єктів у ній задіяно. Також Д.Плинокос уточнює, які суб’єкти та яка їхня кількість задіяна на кожному етапі, зокрема такі як от:

- заклади вищої освіти;

- фірми-посередники;

- Міністерство освіти та науки;

- консульські установи;

- Служба безпеки України;

- Державна прикордонна служба [9, с.15].

Іноземні студенти зазвичай мають певні труднощі, проблеми, бар'єри, ризики тощо, оскільки вони попадають у нове мовне та соціокультурне середовище. Слід відмітити, що проблема соціокультурної адаптації є досить складною та водночас вагомою для всіх вітчизняних закладів вищої освіти. Як правило, у структурі кожного вітчизняного закладу вищої освіти є підрозділ (підготовче відділення або факультет), що здійснює мовну, первинну фахову підготовку іноземних студентів до вступу до закладів вищої освіти протягом десяти місяців відповідно терміну заїзду.

Підготовчі відділення діють відповідно до Закону України «Про правовий статус іноземців та осіб без громадянства» №3929-XII від 04.02.1994 р. [10], Наказу Міністерства освіти і науки України №1541 «Деякі питання організації набору та навчання (стажування) іноземців та осіб без громадянства» від 01.11.2013. [11], Наказу Міністерства освіти і науки України № 1272 «Про внесення змін до наказу Міністерства освіти і науки України від 01.11.2013 № 1541» від 11.12.2015 р., Постанови Кабінету Міністрів України №136 «Про навчання іноземних громадян в Україні» від 26.02.1993 р. [12], Постанови Кабінету Міністрів України №684 «Деякі питання набору для навчання іноземних та осіб без громадянства» від 11 вересня 2013 року тощо.

Підвищити мовну компетентність на підготовчих курсах (відділенні, факультеті) мають можливість іноземні громадяни та особи без громадянства, які прибувають в Україну на навчання. Після успішного завершення навчання майбутні студенти отримують сертифікат та вступають до закладу вищої освіти. 
Журнал«Герспективитаінновації наукиљ

(Серія «Гедагогіка», Серія«ГЕихологія», Серія«Медицина»

№1(6) 2022

Значення діяльності підготовчих курсів (підготовчого етапу, довузівської підготовки) важко переоцінити, оскільки студенти, прибувши в Україну, потрапляють у стресову ситуацію, а протягом десяти місяців вони мають можливість, завдяки планомірній організації навчання, соціокультурно адаптуватися.

А. Суригін, який вбачає вагоме значення підготовчого етапу в освітньому процесі, оскільки цей етап передбачає навчання студентів-іноземців, які орієнтовані на конкретну професійну галузь, нерідною для них мовою, якою буде пізніше здійснюватись навчання, в «умовах інтенсивної соціальнобіологічної адаптації» [13].

Виходячи 3 того, що мовне середовище відіграє найважливішу роль у соціокультурній адаптації іноземних студентів, на підготовчому відділенні навчання проводиться на англійській та українській мовах. Особливостями навчання іноземних студентів на підготовчих факультетах $є$ такі:

- застосування відповідної методики навчання, яка забезпечуватиме перехід від одного мовного середовища до іншого;

- актуалізація опорних знань студентів та застосування їх у іншомовному середовищі;

- організація самостійної роботи 3 урахуванням рівня адаптації студентів-іноземців тощо [14, с. 561].

Коли молода людина потрапляє в іншу країну та навіть тимчасово змінює місце проживання - це стресова ситуація. Окрім проблеми іншомовного середовища, безумовно це пов'язано зі зміною побуту, умов, пристосуванням до нового колективу, знайомством із традиціями, звичаями та культурою, нормами поведінки, етикетом та менталітетом українців, а також 3 іншою системою освіти. Особливо складно студентам-іноземцям доводиться у перші місяці навчання, перебуваючи в іншій країні. Саме в перші місяці студенти мають оволодіти досить великим обсягом знань, ознайомитися 3 новими дисциплінами, вчити мову для подальшого навчання. Не маючи досвіду досить складно в іншомовному середовищі адаптуватися до нових вимог та умов. Тому навчання на підготовчому відділенні для них являється базовим та сприяє швидшому процесу адаптації.

Окрім цього іноземні студенти постають перед необхідністю занурення не лише в нові знання, але й в нову культуру (акультурація) [15, с.155]. Студентам-іноземцям доводиться, окрім опанування професійними навичками, знайомитися та опановувати культуру країни, у якій вони перебувають, долучатися до її етносу та духовного багатства [16, с.13]. Це в свою чергу $\epsilon$ запорукою розвитку толерантності, поваги до інших культур, формування творчої особистості. Н. Стеніна зазначає, що в іноземних студентів формується система цінностей, способів діяльності та саме власна картина світу під час активної комунікативної взаємодії [17, с.12].

I. Штейміллер, досліджуючи проблему науково-методичного забезпечення іноземних студентів, наголошує на необхідності формування в 
іноземних студентів міжкультурних цінностей, що дасть змогу налагоджувати комунікації з різними людьми, критично мислити та формулювати оцінні судження як про різні об'єкти реальності, так і про власне «Я» $[18 ; 19]$.

О. Білик, досліджуючи проблему соціалізації іноземних студентів в освітньокультурному середовищі вищого навчального закладу, акцентує увагу на важливості мовної соціалізації, оскільки мовлення формує мислення, орієнтує в діяльності та допомагає адаптуватися до нових вимог [20, с.179]. Слід зазначити, що в пригоді стали наукові розвідки Н. Ушакової, В. Дубчинського, О. Тростинської, де обгрунтовано, що «українська (російська) мови є для іноземців не лише навчальним предметом, а й освітньою дисципліною, засобом усестороннього розвитку впродовж життя та провідником майбутніх фахівців у їх становленні як професійних особистостей» [21, с.137]. Досягнення іноземними студентами рівня володіння мовою (українською або російською як іноземною) А1, А2, В1, здійснюється на підготовчому відділенні (факультеті), що є початковим етапом навчання, як зазначалося вище [21].

Нам імпонує думка науковців щодо важливості мовної підготовки на підготовчому відділенні (факультеті), оскільки це забезпечує комунікативні потреби студентів-іноземців у різних сферах спілкування - від побутової до наукової. При цьому заклади вищої освіти враховують вибір іноземних студентів, власні освітні можливості, а також умови контракту, де визначено якою мовою буде проходити навчання. Зазвичай це може бути українська, російська або англійська мова. Зміст мовної підготовки студентів на підготовчих відділеннях визначається відповідно комунікативних потреб іноземців, а також профілю навчання.

У пригоді стало дослідження В. Головко, яка у дисертаційній роботі зазначає, що «...більшість навчального часу на підготовчому етапі навчання відводиться саме на вивчення майбутніми фахівцями мови» [22, с. 93]. Науковиця зазначає, що саме такий спеціально організований підхід до навчання іноземних студентів сприяє їхній адаптації, оскільки створюються відповідні умови життєдіяльності в новому для них соціокультурному середовищі [22, с.93].

Чільне місце в мовній підготовці іноземних студентів відводиться навчанню професійної лексики відповідно спрямуванню за фахом, вибору факультету тощо. Якісне оволодіння студентами потрібним мовним професійним базисом на підготовчому відділенні $\epsilon$ запорукою успішного професійного становлення майбутніх фахівців [22; 23; 24; 25$]$.

3 огляду на це, мовна підготовка іноземних студентів на підготовчому відділенні спрямована на вирішення таких завдань:

-розвиток комунікативних умінь за видами мовленнєвої діяльності (говоріння, аудіювання, читання, письмо);

-оволодіння мовними знаннями, необхідними для професійнокомунікативного спілкування (знання фонетики, граматичних правил, лексичних одиниць тощо); 
Журнал«Герспективита інноваціїнукиљ

(Серія «Гедагогіка», Серія «Гиихологія», Серія «Медицинв»

№(6) 2022

- формування соціокультурних знань, які допомагають іноземним студентам знати культуру, історію, традиції мови;

'оволодіння набором одиниць професійної лексики (лексика, терміни, поняття) тощо [22; 23; 24; 25; 26].

Мовна підготовка сприяє якісному оволодінню знаннями щодо особливостей майбутньої професійної діяльності [68, с. 34].

Для оволодіння іноземними студентами потрібним мовним професійним базисом, науковці радять приділяти значну увагу оволодінню:

·уміннями спілкування-діалогу як комунікативно-мовної взаємодії;

·моделями та вміннями внутрішньогрупового суб'єкт - суб'єктної та міжгрупової колективної взаємодії;

· професійним лексиконом;

· соціокультурними та професійно-орієнтованими ситуаціями, професійносоціальним контекстом;

-уміннями, прийомами та засобами створювати свій творчий мовний продукт [22; 26: 28].

Нам імпонує думка Р. Гришкової щодо того, що професійно-орієнтовані тексти мають бути пов'язані 3 актуальними професійними проблемами, відображати практичні потреби студентів, спрямовувати на їхню майбутню професійну діяльність та бути соціально вмотивованими [29, с. 97]. 3 огляду на це робота з текстами фахового спрямування сприяє збагаченню:

· загальної й професійно-орієнтованої термінологічної лексики;

- мовленнєвої діяльності студентів;

- оптимальної результативності формування професійно спрямованої комунікативної мовленнєвої компетенції фахівців відповідної сфери [29, с. 10].

Як було вже зазначено вище, іноземні студенти після завершення курсу навчання на підготовчому відділенні (факультеті) отримують професійну освіту на обраному факультеті обраного закладу вищої освіти. Слід уточнити, що найпопулярнішими вітчизняними університетами серед іноземних студентів $є$ такі, як от: Харківський національний університет імені В.Н.Каразіна, Харківський національний медичний університет, Національний медичний університет імені О.О. Богомольця, Одеський національний медичний університет, Запорізький державний медичний університет, Вінницький національний медичний університет імені М.I. Пирогова, Дніпровський державний медичний університет та інші [30].

Отже, особливістю навчання іноземних студентів у вишах України $є$ якісна організація мовної підготовки, що здійснюється на підготовчих відділеннях (факультетах).

О. Сегеда й А. Осипенко аналізуючи особливості адаптації іноземних студентів до освітнього середовища України, зазначають, що професійно орієнтоване навчання іноземних студентів грунтується на особливостях майбутньої професії, а також поєднує в собі «оволодіння професійно орієнтованою мовою, розвиток особистісних якостей студента-суб'єкта 
навчання, знання культури країни навчання та набуття спеціальних умінь, заснованих на професійних і лінгвістичних знаннях» [31].

Висновки. Таким чином, іноземні здобувачі вищої освіти свідомо обирають навчання в українських закладах вищої освіти, базуючись на низці факторів й переваг перед 3 ВО інших країн. Діяльність факультетів 3 підготовки іноземних громадян вдіграють значну роль у системі підготовки та сприяють ефективній соціокультурній та мовній адаптації іноземних студентів.

\section{Лimepamypa:}

1. Оригінал новини «Україна на міжнародному ринку освітніх послуг вищої освіти»- http://www.euroosvita.net/index.php/?category=1\&id=3758

2. «Євро Освіта» - http://www.euroosvita.net/index.php

3. Кабінет Міністрів України 21 квітня 2021 року №350-р «План заходів щодо популяризації можливостей здобуття вищої освіти в Україні для іноземних студентів до 2025 року» https://www.kmu.gov.ua/npas/pro-zatverdzhennya-planu-zahodiv-sh-a350r

4. Верховна рада України. Указ Президента України «Про вдосконалення вищої освіти в Україні» https://zakon.rada.gov.ua/laws/show/210/2020\#Text

5. Мазитова Л. Т. Социальная адаптация иностранных студентов : на примере вузов Башкортостана : дис. ... канд. соц. наук : 22.00.04 / Л. Т. Мазитова. Уфа, 2002. 154 с.

6. Корощенко А.В., Асмоах Джошуа Проблемы и особенности обучения иностранных студентов на английском языке http://ea.donntu.edu.ua/bitstream/123456789/ 21739/1/ \%D0\%9F\%D0\%A0\%D0\%9E\%D0\%91\%D0\%9B\%D0\%95\%D0\%9C\%D0\%AB\%20\%D0\%98\%20\% D0\%9E\%D0\%A1\%D0\%9E\%D0\%91\%D0\%95\%D0\%9D\%D0\%9D\%D0\%9E\%D0\%A1\%D0\%A2\%D 0\%98\%20\%D0\%9E\%D0\%91\%D0\%A3\%D0\%A7\%D0\%95\%D0\%9D\%D0\%98\%D0\%AF.pdf

7. Плинокос Д. Особливості здійснення експорту освітніх послуг в Україні. Матеріали V Міжнародної науково-методичної конференції «Актуальні питання організації навчання іноземних студентів в Україні. 14-16 жовтня 2020 р. Тернопіль. С. 14-17.

8. Закон України «Про правовий статус іноземців та осіб без громадянства» (ред. 2011 p) https://zakon.rada.gov.ua/laws/show/3929-12\#Text

9. Плинокос Д. Особливості здійснення експорту освітніх послуг в Україні. Матеріали V Міжнародної науково-методичної конференції «Актуальні питання організації навчання іноземних студентів в Україні. 14-16 жовтня 2020 р. Тернопіль. С. 14-17.

10. Закон України «Про правовий статус іноземців та осіб без громадянства» №3929ХІІ від 04.02.1994 p. - https://zakon.rada.gov.ua/laws/show/3929-12\#Text

11. Наказ Міністерства освіти і науки України №1541 «Деякі питання організації набору та навчання (стажування) іноземців та осіб без громадянства» (ред.2021) https://zakon.rada.gov.ua/laws/show/z2004-13\#Text

12. Постанова Кабінету Міністрів України №136 «Про навчання іноземних громадян в Україні» (ред.2018) https://zakon.rada.gov.ua/laws/show/136-93-\%D0\%BF\#Text

13. Сурыгин А. И. Дидактические основы предвузовской подготовки иностранных студентов в высших учебных заведениях. СПб : Нестор, 2000. С. 30.

14. Романова Т.А., Виндижева М.К., Сабанова Р.К., Мамаева Ж.М. Особенности обучения иностранных студентов на подготовительных факультетах. Педагогический журнал. 2018. Т. 8. № 5А. С. 559-567.

15. Білик О.М. Теорія та методика соціалізації іноземних студентів в освітньокультурному середовищі вищого навчального закладу. Дис....на здоб. доктора пед.наук. 13.00.05 «Соціальна педагогіка» - Харківська державна академія культури, Харків; 
Державний заклад «Луганський національний університет імені Тараса Шевченка», Старобільськ, 2018. 683 с.

16. Стенина Н. С. Формирование профессиональной компетенции иностранных студентов, обучающихся в высших художественных учебных заведениях России : автореф. дис. ... канд. пед. наук : 13.00.08 «Теория и методика профессионального образования». М., 2007. 20 с.

17. Стенина Н. С. Формирование профессиональной компетенции иностранных студентов, обучающихся в высших художественных учебных заведениях России : автореф. дис. ... канд. пед. наук : 13.00.08 «Теория и методика профессионального образования». М., 2007. 20 с.

18. Штейміллер I. О. Науково-методичне забезпечення акультурації іноземних студентів класичного університету : автореф. дис. ... канд. пед. наук : 13.00.07 «Теорія навчання» / Харків. нац. ун-т ім. В. Н. Каразіна. Харків, 2015. 20 с.

19. Штейміллер I. О. Педагогічний супровід соціокультурної адаптації іноземних студентів під час навчання в українському університеті. Актуальні проблеми державного управління, педагогіки та психологї̈. 2014. Вип. 2. С. 97- 100.

20. Білик О.М. Теорія та методика соціалізації іноземних студентів в освітньокультурному середовищі вищого навчального закладу. Дис....на здоб. доктора пед.наук. 13.00.05 «Соціальна педагогіка» - Харківська державна академія культури, Харків; Державний заклад «Луганський національний університет імені Тараса Шевченка», Старобільськ, 2018. 683 с.

21. Ушакова Н. I., Дубічинський В. В., Тростинська О. М. Концепція мовної підготовки іноземців у ВНЗ України. Викладання мов у вищих навчальних закладах на сучасному еmani : міжпредметні зв'язки : зб. наук. пр. Харків. 2011. Вип. 19. С. 136-146.

22. Головко В. А Педагогічний супровід професійного самовиховання іноземних студентів у вищих технічних навчальних закладах. - дис. на здобуття наук.ступеня канд.пед. наук : спец.13.00.07 “Теорія та методика виховання” / В.В.Головко. Харків, 2015 - 239 с.

23. Палка О. В. Підготовка іноземних студентів вищих навчальних закладів України технічного профілю до вивчення професійної лексики : автореф. ... дис. канд. пед. наук : 13.00.04 / О. В. Палка. - К., 2003. - 18 с.

24. Субота Л. А. Комунікативний підхід до навчання професійно-орієнтованому читанню іноземних студентів у немовному ВНЗ Одеський лінгвістичний вісник. 2015. № 5. T. 2. C. $149-153$.

25. Субота Л. А. Самостійна навчальна діяльність іноземних студентів у вивченні текстів за професійним спрямуванням. Вісник Запорізького національного університету. Запор. нац. ун-т, 2012. № 1(17). С. 188-191.

26. Батраева О. М. Практическая работа над языком специальности иностранных студентов, изучающих дисциплину «Профессиональный иностранный язык II» в техническом вузе. Концелт. 2015. Т. 27. С. 141-145. URL: http://ekoncept.ru/2015/65529.htm.

27. Семененко I.C. Особливості фахової підготовки іноземних студентів вищих технічних навчальних закладів. Педагогічний процес: теорія і практика. Вип. 2. 2014. С.33-36.

28. Хинзеева Н.П. Формирование комуникативной компетентности иностранных студентов в иноязычной образовательной среде. Дис. ...канд.пед.наук. 13.00.01 Улан-Уде. 2017. $189 \mathrm{c}$.

29. Гришкова Р. О. Реалізація оновленого змісту англомовної підготовки студентів нефілологічних спеціальностей в умовах сьогодення. Наукові праџі Чорноморського державного університету імені Петра Могили комплексу "Києво-Могилянська академія". Cер. : Педагогіка. 2010. Т. 123. Вип. 110. С. 94-98.

30. Міністерство освіти і науки України Український державний центр міжнародної освіти. Іноземні студенти в Україні. https://studyinukraine.gov.ua/zhittya-v-ukraini/inozemnistudenti-v-ukraini/ 
31. Сегеда О. О., Осипенко А. А. Особливості адаптації іноземних студентів до освітнього середовища України. Психологія. Харків. 2014. Вип. 48. С. 205-208.

\section{References:}

1. Original novini «Ukraïna na mizhnarodnomu rinku osvitnih poslug vishhoï osviti» [Original news "Ukraine in the international market of higher education services"]. www.euroosvita.net. Retrieved from http://www.euroosvita.net/index.php/?category=1\&id=3758 [in Ukrainian].

2. «Evro Osvita» ["Euro Education"].www.euroosvita.net. Retrieved from www.euroosvita.net. Retrieved from http://www.euroosvita.net/index.php/?category=1\&id=3758 [in Ukrainian].

3. Kabinet Ministriv Ukraïni «Plan zahodiv shhodo populjarizaciï mozhlivostej zdobuttja vishhoï osviti v Ukraïni dlja inozemnih studentiv do 2025 roku» [The Cabinet of Ministers of Ukraine April 21, 2021 50350-r "Plan of measures to promote opportunities for higher education in Ukraine for foreign students until 2025"].(n.d.). www.kmu.gov.ua. Retrieved from https://www.kmu.gov.ua/npas/pro-zatverdzhennya-planu-zahodiv-sh-a350r [in Ukrainian].

4. Ukaz Prezidenta Ukraïni «Pro vdoskonalennja vishhoï osviti v Ukraïni» [Decree of the President of Ukraine "On Improving Higher Education in Ukraine"].(n.d.). zakon.rada.gov.ua. Retrieved from https://zakon.rada.gov.ua/laws/show/210/2020\#Text [in Ukrainian].

5. Mazitova L. T. (2002). Social'naja adaptacija inostrannyh studentov : na primere vuzov Bashkortostana [Social adaptation of foreign students: on the example of universities of Bashkortostan]. Candidate's thesis. Ufa [in Ukrainian].

6. Koroshhenko, A.V., Asmoah, Dzhoshua Problemy i osobennosti obuchenija inostrannyh studentov na anglijskom jazyke [Problems and features of teaching foreign students in English]. ea.donntu.edu.ua/bitstream Retrieved from http://ea.donntu.edu.ua/bitstream/123456789/21739/ 1/\%D0\%9F\%D0\%A0\%D0\%9E\%D0\%91\%D0\%9B\%D0\%95\%D0\%9C\%D0\%AB\%20\%D0\%98\% 20\%D0\%9E\%D0\%A1\%D0\%9E\%D0\%91\%D0\%95\%D0\%9D\%D0\%9D\%D0\%9E\%D0\%A1\%D0 $\% \mathrm{~A} 2 \% \mathrm{D} 0 \% 98 \% 20 \% \mathrm{D} 0 \% 9 \mathrm{E} \% \mathrm{D} 0 \% 91 \% \mathrm{D} 0 \% \mathrm{~A} 3 \% \mathrm{D} 0 \% \mathrm{~A} 7 \% \mathrm{D} 0 \% 95 \% \mathrm{D} 0 \% 9 \mathrm{D} \% \mathrm{D} 0 \% 98 \% \mathrm{D} 0 \% \mathrm{~A}$ F.pdf[in Ukrainian].

7. Plinokos, D. (2020). Osoblivosti zdijsnennja eksportu osvitnih poslug v Ukraïni [Features of the export of educational services in Ukraine.]. Proceedings from $V$ Mizhnarodno $\ddot{~}$ naukovo-metodichnoï konferenciï «Aktual'ni pitannja organizacï navchannja inozemnih studentiv $v$ Ukraïni - The V International Scientific and Methodological Conference "Current issues of education of foreign students in Ukraine”. (pp. 109-111). Ternopil' [in Ukrainian].

8. Zakon Ukraïni «Pro pravovij status inozemciv ta osib bez gromadjanstva» [The Law of Ukraine «On the Legal Status of Foreigners and Stateless Persons»]. (n.d.). zakon.rada.gov.ua. Retrieved from https://zakon.rada.gov.ua/laws/show/3929-12\#Text [in Ukrainian]

9. Plinokos, D. (2020). Osoblivosti zdijsnennja eksportu osvitnih poslug v Ukraïni [Features of the export of educational services in Ukraine.]. Proceedings from V Mizhnarodnoi naukovo-metodichnoï konferenciï «Aktual'ni pitannja organizaciï navchannja inozemnih studentiv v Ukrä̈n - The V International Scientific and Methodological Conference "Current issues of education of foreign students in Ukraine”. (pp. 109-111). Ternopil' [in Ukrainian].

10. Zakon Ukraïni «Pro pravovij status inozemciv ta osib bez gromadjanstva» [The Law of Ukraine «On the Legal Status of Foreigners and Stateless Persons»]. (n.d.). zakon.rada.gov.ua. Retrieved from https://zakon.rada.gov.ua/laws/show/3929-12\#Text [in Ukrainian]

11. Nakaz Ministerstva osviti i nauki Ukraïni «Dejaki pitannja organizaciï naboru ta navchannja (stazhuvannja) inozemciv ta osib bez gromadjanstva» [Order of the Ministry of Education and Science of Ukraine "Some issues of organization of recruitment and training (internship) of foreigners and stateless persons"].(n.d.). zakon.rada.gov.ua. Retrieved from https://zakon.rada.gov.ua/laws/show/z2004-13\#Text [in Ukrainian]

12. Postanova Kabinetu Ministriv Ukraïni «Pro navchannja inozemnih gromadjan v Ukraïni» [Resolution of the Cabinet of Ministers of Ukraine 36136 "On the training of foreign 
citizens in Ukraine"].(n.d.). zakon.rada.gov.ua. Retrieved from https://zakon.rada.gov.ua/laws/ show/136-93-\%D0\%BF\#Text [in Ukrainian]

13. Surygin, A. I. (2000). Didakticheskie osnovy predvuzovskoj podgotovki inostrannyh studentov v vysshih uchebnyh zavedenijah [Didactic bases of pre-university training of foreign students in higher educational institutions]. SPb : Nestor [in Russian].

14. Romanova, T.A., Vindizheva, M.K., Sabanova, R.K., Mamaeva, Zh.M. (2018). Osobennosti obuchenija inostrannyh studentov na podgotovitel'nyh fakul'tetah [Features of teaching foreign students at the preparatory faculties]. Pedagogicheskij zhurnal - Pedagogical journal, 8, 5A, 559-567 [in Russian].

15. Bilik, O.M. (2018). Teorija ta metodika socializaciï inozemnih studentiv v osvitn'okul'turnomu seredovishhi vishhogo navchal'nogo zakladu [Theory and methods of socialization of foreign students in the educational and cultural environment of higher education]. Doctor's thesis. Harkiv: Derzhavnij zaklad «Lugans'kij nacional'nij universitet imeni Tarasa Shevchenka» [in Ukrainian].

16. Stenina, N. S. (2007). Formirovanie professional'noj kompetencii inostrannyh studentov, obuchajushhihsja v vysshih hudozhestvennyh uchebnyh zavedenijah Rossii [Formation of professional competence of foreign students studying in higher art educational institutions of Russia].Extended abstract of candidate's thesis. M [in Russian].

17. Stenina, N. S. (2007). Formirovanie professional'noj kompetencii inostrannyh studentov, obuchajushhihsja $\mathrm{v}$ vysshih hudozhestvennyh uchebnyh zavedenijah Rossii [Formation of professional competence of foreign students studying in higher art educational institutions of Russia].Extended abstract of candidate's thesis. M [in Russian].

18. Shtejmiller, I. O. (2015). Naukovo-metodichne zabezpechennja akul'turacii inozemnih studentiv klasichnogo universitetu [Scientific and methodological support of acculturation of foreign students of the classical university]. Extended abstract of candidate's thesis. Harkiv: nac. un-t im. V. N. Karazina. Harkiv [in Ukrainian].

19. Shtejmiller, I. O. (2014). Pedagogichnij suprovid sociokul'turnoï adaptaciï inozemnih studentiv pid chas navchannja v ukraïns'komu universiteti [Pedagogical support of socio-cultural adaptation of foreign students while studying at a Ukrainian university]. Aktual'ni problemi derzhavnogo upravlinnja, pedagogiki ta psihologii [Current issues of public administration, pedagogy and psychology], 2, 97-100 [in Ukrainian].

20. Bilik, O.M. (2018). Teorija ta metodika socializaciï inozemnih studentiv v osvitn'okul'turnomu seredovishhi vishhogo navchal'nogo zakladu [Theory and methods of socialization of foreign students in the educational and cultural environment of higher education]. Doctor's thesis. Harkiv: Derzhavnij zaklad «Lugans'kij nacional'nij universitet imeni Tarasa Shevchenka» [in Ukrainian].

21. Ushakova, N. I., Dubichins'kij, V. V., Trostins'ka, O. M. (2011). Koncepcija movnoï pidgotovki inozemciv u VNZ Ukraïni [The concept of language training of foreigners in Ukrainian universities]. Vikladannja mov u vishhih navchal'nih zakladah na suchasnomu etapi - Teaching languages in higher education at the present stage, 19, 136-146 [in Ukrainian].

22. Golovko, V. A (2015). Pedagogichnij suprovid profesijnogo samovihovannja inozemnih studentiv $\mathrm{u}$ vishhih tehnichnih navchal'nih zakladah [Pedagogical support of professional self-education of foreign students in higher technical educational institutions]. Candidate's thesis. Harkiv [in Ukrainian].

23. Palka, O. V. (2003). Pidgotovka inozemnih studentiv vishhih navchal'nih zakladiv Ukraïni tehnichnogo profilju do vivchennja profesijnoï leksiki [Preparation of foreign students of higher educational institutions of Ukraine of technical profile for the study of professional vocabulary].Extended abstract of candidate's thesis. Kiev [in Ukrainian].

24. Subota, L. A. (2015). Komunikativnij pidhid do navchannja profesijno-orientovanomu chitannju inozemnih studentiv u nemovnomu VNZ [Communicative approach to teaching professionally-oriented reading to foreign students in a non-language university]. Odes'kij lingvistichnij visnik - Odessa Linguistic Bulletin, 5, 2, 149-153 [in Ukrainian]. 
25. Subota, L. A. (2012). Samostijna navchal'na dijal'nist' inozemnih studentiv u vivchenni tekstiv za profesijnim sprjamuvannjam [Independent educational activities of foreign students in the study of texts in the professional field]. Visnik Zaporiz'kogo nacional'nogo universitetu Bulletin of Zaporizhia National University, 1(17), 188-191 [in Ukrainian].

26. Batraeva, O. M. (2015). Prakticheskaja rabota nad jazykom special'nosti inostrannyh studentov, izuchajushhih disciplinu «Professional'nyj inostrannyj jazyk II» v tehnicheskom vuze [Practical work on the language of the specialty of foreign students studying the discipline "Professional Foreign Language II" in a technical university]. Koncept - Concept, 27, 141-145 [in Russian].

27. Semenenko, I.C. (2014). Osoblivosti fahovoï pidgotovki inozemnih studentiv vishhih tehnichnih navchal'nih zakladiv [Features of professional training of foreign students of higher technical educational institutions]. Pedagogichnij proces: teorija i praktika-Pedagogical process: theory and practice, 2, 33-36 [in Ukrainian].

28. Hinzeeva, N.P. (2017). Formirovanie komunikativnoj kompetentnosti inostrannyh studentov $\mathrm{v}$ inojazychnoj obrazovatel'noj srede [Formation of communicative competence of foreign students in a foreign language educational environment].Candidate's thesis. Ulan-Ude [in Russian].

29. Grishkova, R. O. (2010). Realizacija onovlenogo zmistu anglomovnoï pidgotovki studentiv nefilologichnih special'nostej $\mathrm{v}$ umovah s'ogodennja [Implementation of the updated content of English-language training of students of non-philological specialties in today's conditions]. Naukovi praci Chornomors'kogo derzhavnogo universitetu imeni Petra Mogili kompleksu "Kicvo-Mogiljans'ka akademija". Ser. : Pedagogika - Scientific works of the Petro Mohyla Black Sea State University of the Kyiv-Mohyla Academy complex. Ser. : Pedagogy, 123, 110, 94-98 [in Ukrainian].

30. Ministerstvo osviti i nauki Ukraïni Ukraïns'kij derzhavnij centr mizhnarodnoï osviti. Inozemni studenti v Ukraïni [Ministry of Education and Science of Ukraine Ukrainian State Center for International Education. International students in Ukraine]. studyinukraine.gov.ua Retrieved from https://studyinukraine.gov.ua/zhittya-v-ukraini/inozemni-studenti-v-ukraini/ [in Ukrainian].

31. Segeda, O. O., Osipenko, A. A. (2014). Osoblivosti adaptaciï inozemnih studentiv do osvitn'ogo seredovishha Ukraini [Features of adaptation of foreign students to the educational environment of Ukraine]. Psihologija - Psychology, 48, 205-208 [in Ukrainian]. 